УДК 784.3

DOI https://doi.org/10.24919/2308-4863/34-3-10

\title{
Ольга НОВАК,
}

викладач кафедри мистеиьких дисииплін

Ужсгородського інституту культури і мистеитв

(Ужгород, Україна) о_novak6493-9@ubogazici.in

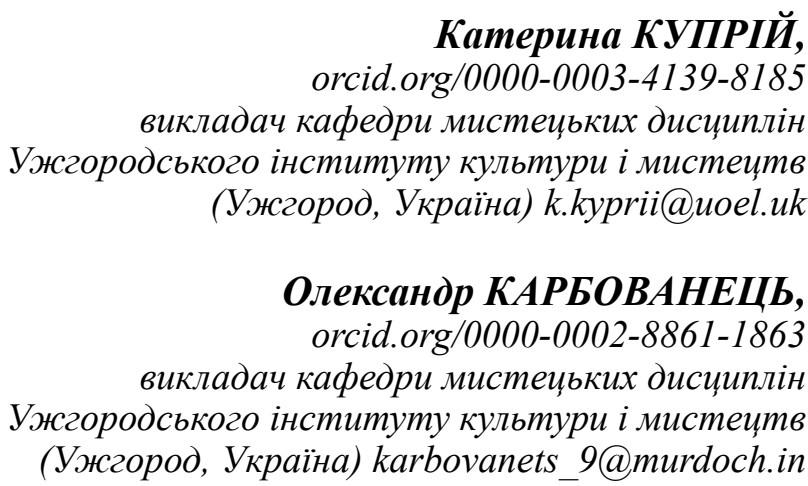

\section{ОСОБЛИВОСТІ СТИЛІСТИКИ ВОКАЛЬНИХ ТВОРІВ} А. КОС-АНАТОЛЬСЬКОГО

У даному науковому дослідженні обговорюються питання особливостей стилістики вокальних творів КосАнатольського. Видатний украӥнський та радянський композитор Кос-Анатольський залишив величезну пісенну спадщину, основу якої склали пісенні твори, щчо нині входять до золотої скарбниці класичного украӥнського хорового вокалу та мають у своєму підтрунті пісенне багатство Прикарпаття, відображення в народній пісні життя та побуту українських горян. Вокальні твори композитора відрізняються неповторною стилістикою, щь щеедро увібрала до себе різноманітні інтонащії, фольклорні форми, поширені в західних областях України. Актуальність тематики даного наукового дослідження зумовлюється нагальною потребою вивчення культури українського народу, щзо яскраво відбивається у творчому шиляху видатних діячів вокального жанру. Методологія даного дослідження має у своїй основі системний підхід до широкого кола питань, тісно пов'язаних із пісенною творчістю А. Кос-Анатольського в поєднанні із глибоким аналізом стилістики його вокальних творів заради визначення їхніх характерних особистостей. Основними результатами даного наукового дослідження доречно вважати визначення основних особливостей стильового наповнення вокальних творів А. Кос-Анатольського та підкреслення його величезного вкладу у вокальну та музичну скарбниџю культури украӥнської пісні. Перспективи подальших наукових досліджень у визначеному напрямку полягають у можливості визначити головні особливості стилістичного побудування вокальних творів композитора А. Кос-Анатольського з метою зрозуміння принциипів побудови стилістичної композиції вокального твору, характерної для радянської музичної школи тих часів. Прикладна иінність даного наукового дослідження полягає в більш докорінному вивченні різноманітних аспектів творчого шляху радянського композитора з метою формування висновків щодо основоположних чинників його творчого шляху та можливості застосування на практиці результатів та висновків цуього наукового дослідження з метою більш досконалого вивчення культурної спадщчни видатних діячів української культури та мистеитва.

Ключові слова: вокальні твори, музична композичія, народні пісні, романс, вокальна творчість. 
Olha NOVAK, orcid.org/0000-0001-6064-1131

Senior Lecturer at the Department of Artistic Disciplines Uzhhorod Institute of Culture and Arts (Uzhhorod,Ukraine)o_novak6493-9@ubogazici.in

Kateryna KYPRII, orcid.org/0000-0003-4139-8185 Senior Lecturer at the Department of Artistic Disciplines Uzhhorod Institute of Culture and Arts (Uzhhorod, Ukraine) k.kyprii@uoel.uk

Oleksandr KARBOVANETS, orcid.org/0000-0002-8861-1863

Senior Lecturer at the Department of Artistic Disciplines Uzhhorod Institute of Culture and Arts (Uzhhorod,Ukraine) karbovanets99@murdoch.in

\section{FEATURES OF STYLISTICS OF VOCAL WORKS OF A. KOS-ANATOLSKY}

This study discusses the features of stylistics of vocal works of A. Kos-Anatolsky. The prominent Ukrainian and Soviet composer A. Kos-Anatolsky left behind a huge song heritage based on songs that are now part of the golden treasury of classical Ukrainian choral vocals and are based on the song richness of Prykarpattia, reflection in the folk song of life and routine of Ukrainian mountaineers. The vocal works of the composer are distinguished by a unique style, which generously absorbed various intonations and folklore forms common in the western regions of Ukraine. The relevance of the study is conditioned by the urgent need to investigate the culture of the Ukrainian people, which is clearly reflected in the creative path of prominent figures of the vocal genre. The methodology of this study is based on a systematic approach to a wide scope of issues that are closely related to the art works of A. Kos-Anatolsky in combination with an in-depth analysis of the style of his vocal works to determine their features. The main results of this study include the identification of the main features of the stylistic content of vocal works of A. Kos-Anatolsky and emphasise his huge contribution to the vocal and musical treasury of Ukrainian song culture. Prospects for further research in this area include the ability to determine the main features of the stylistic construction of vocal works by composer A. Kos-Anatolsky in order to understand the principles of construction of stylistic composition of vocal work, typical of the Soviet music school of that time. The applied value of this study is a more thorough study of various aspects of the creative path of the Soviet composer in order to draw conclusions about the fundamental factors of his creative path and the possibility of applying the results and conclusions of this study in practice in order to better explore the cultural heritage of prominent Ukrainian cultural figures.

Key words: vocal works, musical composition, folk songs, romance, vocal creativity.

Постановка проблеми. Вокальна творчість займає особливе місце у творчому доробку видатного українського та радянського композитора А. Кос-Анатольського. Для цього діяча культури та мистецтв властивий неповторний стильовий почерк, що з'явився завдяки його великому пісенному таланту, що своїми складовими частинами тісно пов'язаний із національними традиціями та пісенною культурою рідного краю. Інтонаційноладові, ритмічні властивості карпатського фольклору, просіяні через призму особистого ліричного світосприйняття, надають його вокальним творам особливого колориту та неповторності. Іншим важливим чинником творчого шляху видатного композитора сучасності, що живив його творчість, $є$ народний побутовий романс, що базувався перш за все на зразках західноукраїнської музичної творчості. Побутові ліричні наспіви надають мелодіям А. Кос-Анатольського гнучку м'якість, сентиментально-елегійний відтінок.

Нерідко романсово-побутові та карпатські коломийські мотиви схрещуються у творах композитора, викликаючи до життя досить своєрідний та звабливий своєю мелодійною насиченістю інтонаційний сплав, як, скажімо, в повному ніжності романсі на слова Л. Забашти «Затрембітай мені, вівчарю». Іншою творчою складовою частиною культурної спадщини Кос-Анатольського $\epsilon$ широке застосування поєднань жанрів побутових танців, таких, як полька, вальс тощо.

Також варто зазначити важливу роль, яку у творчій пісенний спадщині композитора відіграють кантата «Безсмертний заповіт» (на власні слова, 1963), вокальний терцет «Шевченко», романс «Не він один» («На роковини Шевченка», на слова Лесі Українки). Також слід зазначити, що 
дуже велику популярність має романс А. Й. КосАнатольского на слова Івана Франка «Ой ти, дівчино, з горіха зерня». Взагалі, романси композитора для колоратурного сопрано стали багаторічною основою репертуару концертних програм таких видатних українських співачок, як Белла Руденко, Свгенія Мірошниченко, Діана Петриненко, Марія Стеф'юк тощо.

Крім того, А. Й. Кос-Анатольский багато фізичних та творчих сил віддав опері та балету, створюючи шедеври сценічної постановки цих двох жанрів театрального мистецтва. Особливо вагомим стало слово А. Кос-Анатольського у розвитку українського балету. Балетна музика займає найважливіше місце в його творчий спадщині. Але до історії української музичної культури композитор А. Й. Кос-Анатольский увійшов, перш за все, як творець неповторних романсів та вокальних творів на основі побутового народного романсу. Унікальна стилістична наповненість цих шедеврів вокального мистецтва зумовлює їхню широку популярність за часів СРСР та вже після смерті митця у 1983 році. Його хорові твори та пісні для сольного виконання дістали справді всенародне визнання. Створені ним вокальні ансамблі являють собою дуже цікавий аспект його творчого шляху. Це не тільки переклади сольних пісень та народних романсів, а й спеціально написані твори. Особливо багато 3 них написано для жіночого вокального тріо, квартету, чоловічих дуетів та квартетів.

Розмаїття творчого внеску композитора у скарбничку української пісенної культури справді вражає. Тому слід вважати за необхідне ретельне вивчення особливостей його творчого шляху з метою виявлення характерних рис постановки вокальної композиції та особливостей ï стилістичного забарвлення. Це буде мати важливе значення $з$ точки зору аналізу творчого доробку видатного композитора та його впливу на формування української пісенної культури в минулому ХX столітті.

Аналіз досліджень. Різноманітні аспекти творчого шляху відомого українського, радянського композитора А. Й. Кос-Анатольского знайшли своє відображення в дослідженнях авторів: Й. Волинського (1965), А. Терещенко (1986), Л. Кияновської (2000). У дослідженнях вказаних авторів висвітлюються питання особливостей вокальної творчості композитора А. Й. КосАнатольского з точки зору аналізу його вкладу до скарбниці української та світової пісенної культури та формування об'єктивного уявлення на різноманітні аспекти його творчого доробку.
Також зазначені автори у своїх наукових роботах висловлюють власні думки стосовно особливостей стилістики вокальних творів композитора, його поглядів на питання постановки вокального твору та особливостей його сценічного виконання. Крім того, в дослідженнях вказуються конкретні продовжувачі творчих пісенних традицій композитора, такі як В. Івасюк, Б. Янівський, В. Стегайлов та інші. Робиться наголос на необхідності подальших досліджень творчої спадщини українського митця задля формування більш об'єктивного погляду на характер його творчого доробку, що залишився, та більш глибокого визначення його ролі та місця в український та світовій музичній та пісенній культурах.

Мета статті полягає у висвітленні особливостей вокальної творчості українського, радянського композитора А. Й. Кос-Анатольского, а також у визначенні характерних особливостей стилістики його вокальних творів із метою визначення глибини творчого доробку композитора в контексті його вкладу до скарбниці світової та української вокальної культури.

Виклад основного матеріалу. Як відомо, будь-яке художне творіння починається із задуму. У драматичній постановці пісні він $є$ укладеним у розшифровці його змісту. Кожен режисер має право будь-яку пісню-гру «поставити» по-своєму, залежно від придбаного життєвого досвіду та фахових навичок. Виявлення теми та ідеї формує сценічний образ, у процесі роботи над піснею можуть поглиблюватися, уточнюватися. Звідси необхідність висловити закладене у творі (сформувати «належний» сценічний образ), що можна позначити як ідею, а найбільш важливе завдання пов'язане $з$ відповіддю на питання, заради чого постановник вибрав цю пісню. Також слід ураховувати, як та ким пісня раніше виконувалася, уточнити «запропоновані обставини»: де й коли виник безпосередньо сам твір. Визначається епоха, вік або конкретний часовий період; де - місце дії: регіон або соціальна середа побутування пісні (допоміжними засобами можуть служити жанрові особливості, iї приуроченість).

Жанрову особливість (пісня лірична, хороводна, танцювальна, весільна, жартівлива та ін.) часто можуть підказати саме «пропоновані обставини». Вони диктують і зовнішне вирішення пісні під час іiї виконання (в тому числі й на сцені), характер інтонування: необхідно звернутися до асоціативного образу мислення учасників фольклорного дійства, щоб подача стала «більш точною для виконавців, пробудила їхню творчу фантазію». 
3 огляду на це якісне висвітлювання творчого доробку композитора А. Кос-Анатольского передбачає заглиблення в пісенну культуру України, обговорення іiі найсуттєвіших, найбільш характерних ознак (Ковбасюк, 2016: 79). Адже тільки повною мірою усвідомивши важливість творчого доробку композитора, сутність художньої спрямованості його величезного таланту, можна зробити вірний висновок щодо його справжнього місця на тлі радянської та світової історії пісенного жанру та характерних рис радянського та українського вокального мистецтва загалом. А. КосАнатольский зайняв в історії української музичної культури місце справжнього митця, яскравого та самобутнього творця шляхів її розвитку. Його практична діяльність увібрала до себе типові ознаки цілого покоління, що формувалося та мужніло в перші післявоєнні часи (Голубева, 2013: 96).

Духовний світ Кос-Анатольського був збагачений мудрістю українського народу, що забезпечив його творам силу та глибину сприйняття. Композитор вслухається не тільки в багату спадщину народних мелодій, а й у наспіви, інтонаційні відтінки, що здатні скласти атмосферу того музичного світу, у якому він творив та жив. Сміливо залучає А. Кос-Анатольський до звукової палітри й терпкий присмак гуцульського народного колориту, та гнучку ритміку танго, вальсу, й чітко відбудовані ритмові інтонації пісень-маршів, й інтимну задушевність ліричного побутового романсу. Усе це поєднується у своєрідному органічному синтезі, відзначається оригінальною манерою індивідуального авторського музичного письма (Щурик, 2011: 106).

«Солоспіви», як називав побутові романси та сольні виконання сам митець, займають у його творчому доробку особливе місце та мають особливе значення. Основна їхня маса знаходиться на межі між романсом та сольним виконанням вокальної композиції, до того ж вони більш розвинені, ніж звичайні вокальні партії, але простіші ніж романси. Яскрава індивідуальна образність, зумовлена поетичною основою, ясне і чітке світосприйняття, проста i доступна переважно куплетна форма, мелодичне багатство, щира та відверта емоційність є рисами, що характеризують солоспіви А. Й. Кос-Анатольського. До того ж митець творив багато романсів та пісень на вірші класиків української літератури: Т. Шевченка, І. Франка, Л. Українки. Його улюбленими співавторами були відомі українські поети: В. Сосюра, М. Рильський, П. Воронько, Д. Павличко, І. Кутень. С в творчості Кос-Анатольського також твори на вірші російських поетів: С. Єсє- ніна, Я. Райніса, а також цикл романсів на тексти сонетів В. Шекспіра та чимало вокальних творів на власні тексти (Адаменко, 2013: 95).

Стилістичне наповнення вокальних творів А. Й. Кос-Анатольського визначає характерне мелодійне виконання, що має у своїй основі інтонаційну лексику українського фольклору, музичного оточення та масових пісень. Характерною особливістю пісень та романсів Кос-Анатольського за змістом, формою й жанрами $\epsilon$ їхня надзвичайна відмінність одне від одного, але постійною у них завжди виступає яскрава національна вишуканість. Із народної пісенної творчості композитор позичає теми та образи, різноманітні виражальні можливості. Анатолій Йосипович звертається до різних фольклорних жанрів: епічних, жартівливих, ліричних, танцювальних. У мелодиці його пісень та романсів: інтонаційні звороти, ритміка, ладо-структурні особливості фольклору. Це й запозичення окремих фраз, речень, інтонаційно-ритмічних формул та творче переосмислення окремих ознак місцевого, народного фольклору (Щурик, 2011: 107).

А. Й. Кос-Анатольський писав романси та пісні протягом майже сорока років. Багато в чому цьому сприяли дружні відносини композитора із багатьма художніми колективами, на базі деяких із них він потім створював вокальні твори, як, наприклад, свої кращі вокальні композиції для хору він створив у співпраці з академічною хоровою капелою «Трембіта». Крім того, величезну кількість своїх солоспівів він написав для колоратурного сопрано. За подібністю настроїв та образів вони об'єднані у цикл «Солов'їні романси». Характерними особливостями стилістичного наповнення саме цих вокальних творів можна вважати яскраво змальоване дівоче кохання, біль розлуки, дівочі мрії про щастя. Розмаїття музичних та пісенних інтонацій майстерно передає широку палітри почуттів, що зумовлює неповторні стилістичні особливості цих вокальних творів. Почуття героїв розкриваються на фоні дивовижно-мальовничої української природи. Свідками їх зустрічей стають пишна троянда, червона калина, весняний вітер, а також соловейко - співець їхнього кохання (Щербиніна, 2013: 166).

А. Й. Кос-Анатольський був композитором, для якого мелодія була головною рисою вокального твору, його характерною ознакою. Безумовно, вона має передбачати гармонію та поліфонію. Але знайти саму мелодію, стрижень стильового наповнення музичного твору, було для митця найважливішим. Тут варто зазначити, що митець ніколи та ніде не шукав ультраординарних пісень або наспівів. Дуже часто можна було 3 легкістю 
визначити першоджерело створеної ним мелодії, але ніколи це не були з його боку лише тільки примітивним копіюванням. Це тому, що багато з того, що складало собою оточення композитора, було сприйнято та трактовано ним вельми оригінально, із властивими лише йому одному відчуттям українського національного музичного та пісенного колориту (Дубровний, 2009).

Карпатські гори та полонини, їхня неповторна краса, люди, що мешкають на цій землі - усі ці теми та образи були художньо виведені митцем у солоспівах «Пастушка» (слова I. Кутеня), «Думала смерека» (слова Д. Павличка), «Гуцульщина» (слова А. Патрус-Карпатського). Серед цієї групи вирізняється солоспів «Ой піду я межи гори» (слова автора), який відтворює барвисту картину побуту гуцулів. Тут і чарівний гірський пейзаж «смерекові ліси та бори», і звуки музики на сільському святі, та перші почуття молодої гуцулки. Усе це розмаїття образів втілено у двочастинній формі, динамізованій варіантним розгортанням тем - рапсодичної, імпровізованої та коломийкової. Романс завершується ефектною кодою, блискучим колоратурним вокалізом (Щурик, 2011: 107).

Романси А. Й. Кос-Анатольського для колоратурного сопрано, віртуозно виконані вокальні прийоми органічно вплетені в загальну стильову палітру виконання. Знані співаки високо цінують романси композитора та виконують їх із задоволенням. Робота композитора над стильовою обробкою народної пісні стала справжнім опануванням народної пісні 3 його боку. Перші спроби він створює ще у 1949 році для славетної української співачки Соломії Крушельницької («Ой прийшов я до двору» та «Ой п’ю ж бо я горівоньку»).

Також варто зазначити, що митець дуже любив твори для дітей та часто створював хорові та сольні вокальні партії, твори для ансамблевого виконання, а також музику для дитячих театральних вистав. Серед відомих його пісень загадок для малят варто відзначити «Карпатська легенда», «Сестричка Марійка», «Подарунок мамі» та інші. Для стилістики цих та багатьох інших його дитячих вокальних творів характерно майстерне поєднання ніжної, співучої мелодії та вишуканої вокальної партії, що об'єднуються в неповторній красі свого звучання (Пальгов, 2012: 75).

А. Й. Кос-Анатольський створив багато вокальних створів. При цьому для нього були характерними узгодження з майбутніми виконавцями своїх задумів та особливостями їхньої подальшої творчої реалізації, з урахуванням сприйняття самого виконавця та його стильової виконавської манери. Анатолій Йосипович радився 3 виконавцями, по можливості задовольняв їхні побажання. Міцні творчі зв'язки були в нього з львівськими артистами, солістами оперного театру: народними артистами України Павлом Кармалюком, Ніною Шевченко та іншими.

Варто зазначити, що сам композитор не надавав суттєвого значення своїм масовим пісням. Незважаючи на те, що ним було написано їx більше тридцяти, у світ пішли лише одиниці. Звісно, як відомо, декотрі були написані виключно на замовлення окремих шанувальників його таланту. Із легкої руки Дунаєвського отримав суттєве поширення своєрідний жанр пісні-маршу, та А. Й. Кос-Анатольський не залишився осторонь цього процесу. У багатьох своїх вокальних творах радянської епохи композиторові не вдалося вийти за рамки інтонацій, що складали основу бравурних радянських маршів цієї епохи. Але й тут потрібно віддати митцеві належне, спостерігаючи, $з$ якою наполегливістю він намагався шукати нові шляхи оновлення мелодійної та вокальної складових у цьому жанрі.

Так, наприклад, у його пісні-марші «Ми вічно молоді» вокальна партія виростає 3 гострої ритміки маршу, немов розриваючи собою тісні рамки первісної форми. Дещо схоже можна бачити й в іншому творі митця - пісні «Розмовляла калинонька» на слова А. Пашка. Це приклад того, як, здавалося б, непісенну тема зрошення безводної пустелі можна переосмислити з точки зору іiі нового ліричного наповнення. Композиція виконана у традиціях старовинних народних ліричних пісень, що різко контрастує з безбарвними фокстротами західних виконавців, що складають основу репертуарів деяких естрадних виконавців та «мікрофонних» ансамблів.

Таким чином, варто відзначити, що головними стилістичними особливостями вокальних творів видатного українського та радянського композитора А. Й. Кос-Анатольського $є$ потяг до української народної мелодії та традицій українського пісенного виконання. На всьому своєму творчому шляху митець залишався вірним пісенним традиціям українського народу, тому сьогодні його можна 3 впевненістю віднести до найбільш видатних послідовників національної культури, шанувальників та подвижників національних музичних та пісенних традицій.

Висновки. Вокальні твори композитора А. Й. Кос-Анатольського високо шануються як виконавцями, так і слухачами, до того ж по праву відносяться то скарбнички вітчизняної та світової музичної та пісенної культури. Їхнє мелодичне багатство, різноманітність ритмів та гармоніч- 
них барв, яскрава образність тематики та сюжетів пісень, продумане ставлення до синтезу музики й тексту, багатство форм та жанрів вокальних творів композитора виділяють їх серед широкого розмаїття подібних творів. Зручні теситурні умови, мелодійне голосоведіння, емоціональне образне насичення роблять твори композитора цікавими та бажаними для активного впровадження в репертуар студентів музично-теоретичних факультетів, що значно збагатять духовний та професійний арсенал майбутнього вчителя музики.

Крім того, варто відзначити, що основу стильового наповнення вокальних композицій майстра незмінно складали шедеври української національної пісенної культури. 3 огляду на цей факт можна вважати, що стилістика вокальних творів композитора Кос-Анатольського практично повністю сформувалася під впливом культури українського народного вокалу та національної музичної культури. Український пісенний фольклор має глибокий образотворчій початок, що перетворює пісню в гру, подібну до сценічного дійства. Народні майстри-виконавці, уживаючись в образ, співвідносять переживання героїв пісні 3 особистими враженнями. Це робить виконання пісні справді художнім явищем.

3 огляду на художню складову частину вокальні твори композитора Кос-Анатольського слід вважати справжніми шедеврами національної пісенної культури України, такими, що завжди будуть відрізняти його стильову манеру побудови вокальної композиції від почерку інших українських композиторів-пісенників. Особливості стилістики вокальних творів Кос-Анатольського підкреслюють виразність української пісні та їі здатність передавати яскраву палітру почуттів, що саме й є характерною ознакою класичної пісенної культури українського народу.

\section{СПИСОК ВИКОРИСТАНИХ ДЖЕРЕЛ}

1. Адаменко С. В. Народная песня как основа музыкального фольклора. Культурная жизнь Юга России. 2013. № 1(48). С. 93-96.

2. Волинський Й. Анатолій Йосипович Кос-Анатольський. Київ : Мистецтво, 1965. 76 с.

3. Голубева М. А. К проблеме артикуляции в народно-певческом исполнительстве. Культурная жизнь Юга России. 2013. № 1(48). С. 96-98.

4. Дубровний Т. А. Кос-Анатольський у спогадах сучасників. Львів : Аз-Арт, 2009. 138 с.

5. Кияновська Л. Стильова еволюція Галицької музичної культури XIX-XX ст. Тернопіль : Астон, 2000. 339 с.

6. Ковбасюк А. М. Вплив фонетики української мови на вокальне виконання. Манускрипт. 2016. № 4(66). С. 78-81.

7. Пальгов С. Ю. «Этнокультурный очаг: Опыт характеристики. Культурная жизнь Юга России. 2012. № 2(45). 2012. C. $74-77$.

8. Терещенко А. Анатолій КосАнатольський. Київ : Музична Україна, 1986. 80 с.

9. Щурик Б. А. Вокальна творчість А. Кос-Анатольського. Молодь і ринок. 2011. № 3(74). С. $106-108$.

10. Щербиніна С. В. Вокально-виконавська майстерність народних співаків. Педагогічна освіта. 2013. № 1. C. $163-167$.

\section{REFERENCES}

1. Adamenko S. V. Narodnaya pesnya kak osnova muzyikalnogo folklore [Folk song as the basis of musical folklore]. Kulturnaya zhizn Yuga Rossii, 2013, Nr 1 (48), pp. 93-96 [in Russian].

2. Volynskyi Y. Anatolii Yosypovych Kos-Anatolskyi [Anatoliy Yosypovych Kos-Anatolsky]. Kyiv: Mystetstvo, 1965. 76 p. [in Ukrainian].

3. Golubeva M. A. K probleme artikulyatsii v narodno-pevcheskom ispolnitelstve [On the problem of articulation in folk singing]. Kulturnaya zhizn Yuga Rossii, 2013, Nr 1 (48), pp. 96-98 [in Russian].

4. Dubrovnyi T. A. Kos-Anatolskyi u spohadakh suchasnykiv [A. Kos-Anatolsky in the memoirs of contemporaries]. Lviv: Az-Art, 2009. 138 p. [in Ukrainian].

5. Kiyanovska L. Stilova evolyutsiya Galitskoyi muzichnoyi kultury XIX - XX st. [Stylistic evolution of Galician musical culture of the XIX - XX centuries]. Ternopil: Aston, 2000. 339 p. [in Ukrainian].

6. Kovbasiuk A. M. Vplyv fonetyky ukrainskoi movy na vokalne vykonannia [Influence of phonetics of the Ukrainian language on vocal performance]. Manuskrypt, 2016, Nr 4 (66), pp. 78-81 [in Ukrainian].

7. Palgov S. Yu. "Etnokulturnyiy ochag": Opyit harakteristiki [Ethnocultural hearth: The experience of characteristics]. Kulturnaya zhizn Yuga Rossii, 2012, Nr 2 (45), pp. 74-77 [in Russian].

8. TereshchenkoA.Anatolii KosAnatolskyi [Anatoly Kos-Anatolsky]. Kyiv: Muzychna Ukraina, 1986. 80 p. [in Ukrainian].

9. Shchuryk B. A. Vokalna tvorchist A. Kos-Anatolskoho [Vocal work of A. Kos-Anatolsky]. Molod i rynok, 2011, Nr 3 (74), pp. 106-108 [in Ukrainian].

10. Shcherbynina S. V. Vokalno-vykonavska maisternist narodnykh spivakiv [Vocal and performing skills of folk singers]. Pedahohichna osvita, 2013, Nr 1, pp. 163-167 [in Ukrainian]. 